\title{
The increase in renin during renin inhibition: does it result in harmful effects by the (pro)renin receptor?
}

\begin{abstract}
AH Jan Danser
Renin inhibitors, similar to all renin-angiotensin system (RAS) blockers, increase the plasma concentration of renin because they attenuate the negative feedback effect of angiotensin (Ang) II on renin release. The increase in renin has been suggested to be higher than that during other types of RAS blockade. This could potentially limit the effectiveness of renin inhibition, either because Ang II generation might occur again ('Ang II escape'), possibly even at the levels above baseline, as has been described before for angiotensin-converting enzyme inhibitors, or because high levels of renin will stimulate the recently discovered (pro)renin receptor, and thus induce effects in an Ang-independent manner. This review shows first that the cause(s) of the renin increase during treatment with the renin inhibitor aliskiren is the consequence of a combination of factors, including an assay artifact, allowing the detection of prorenin as renin, and a change in renin half-life. When correcting for these phenomena the increase is unlikely to be as excessive as originally thought. The review then critically describes the consequence(s) of such a increase, concluding (i) that an Ang II escape is highly unlikely, given the [aliskiren]/[renin] stoichiometry, and (ii) that renin and prorenin downregulate their receptor (similar to many agonists). On the basis of the latter, one could even speculate that this will be more substantial when the renin and prorenin levels are higher. Thus, from this point of view the larger increase in renin during renin inhibition will cause a stronger reduction in (pro)renin receptor expression, and a greater suppression of (pro)renin receptor-mediated effects than other renin-Ang blockers.
\end{abstract}

Hypertension Research (2010) 33, 4-10; doi:10.1038/hr.2009.186; published online 6 November 2009

Keywords: angiotensin; prorenin; (pro)renin receptor; renin inhibition; vacuolar $\mathrm{H}^{+}$-ATPase

\section{INTRODUCTION}

Renin inhibitors, similar to all renin-angiotensin system (RAS) blockers, increase the plasma concentration of renin because they attenuate the negative feedback effect of angiotensin (Ang) II on renin release. The increase in renin has been suggested to be higher than that during other types of RAS blockade. ${ }^{1}$ This statement is based on the results of immunoreactive renin assays. Such direct assays still allow the quantification of renin in the presence of a renin inhibitor, unlike the indirect, enzymatic assays that rely on the measurement of renin activity (that is, renin's capacity to generate Ang I).

An excessive increase in renin could potentially limit the effectiveness of renin inhibition, either because Ang II generation might occur again ('Ang II escape'), possibly even at levels above baseline, as has been described before for angiotensin-converting enzyme (ACE) inhibitors, ${ }^{2-4}$ or because high levels of renin will stimulate the recently discovered (pro)renin receptor, and thus induce effects in an Angindependent manner. ${ }^{5-8}$ This review first focuses on the cause(s) of the renin increase during renin inhibition. It then critically reviews the consequence(s) of such an increase, if any.

\section{WHY DOES RENIN INCREASE 'EXCESSIVELY' DURING RENIN INHIBITION?}

Given the interference with the negative feedback loop, as mentioned above, it is not surprising that renin increases during RAS blockade. In fact, it has been suggested that the increase in renin is a reflection of the degree of RAS blockade, that is, that a higher increase in renin reflects superior RAS blockade. ${ }^{9}$ Thus, the simplest explanation for the excessive increase in renin during renin inhibition is that renin inhibitors provide better RAS blockade than ACE inhibitors and/or Ang II type $1\left(\mathrm{AT}_{1}\right)$ receptor blockers. In support of this concept, the renin inhibitor aliskiren exerted additional effects in heart (a further decrease in brain natriuretic peptide ${ }^{10}$ ) and kidney (a further decrease in albuminuria ${ }^{11}$ ) when given on top of what is currently considered 'optimal' RAS blockade (with ACE inihibitors and/or $\mathrm{AT}_{1}$ receptor blockers) in subjects with heart failure or nephropathy, respectively. Aliskiren also induced additional blood pressure-lowering effects on top of other RAS blockers, ${ }^{12}$ and its effects on renal plasma flow were double than that of an ACE inhibitor. ${ }^{13}$ Yet, it did not promote left ventricular mass regression on top of $\mathrm{AT}_{1}$ receptor blockade with 
losartan. ${ }^{14}$ This could relate to the use of additional (non-RASrelated) antihypertensive medication in this trial, resulting in similar blood pressure reductions in all treatment arms.

A second reason why the renin increase is higher than normal may relate to an alteration in renin clearance. Renin clearance largely depends on its glycosylation pattern, as the carbohydrate moieties determine its uptake by Kupffer cells in the liver. ${ }^{15}$ The responsible clearance receptors are, among others, mannose 6-phosphate receptors. ${ }^{16-18}$ These receptors bind and internalize both renin and its inactive precursor, prorenin, and the two enzymes are subsequently degraded intracellularly with a half-life of several hours. Renin inhibitors alter the three-dimensional structure of renin. ${ }^{19}$ As a consequence renin might become more resistant against metabolizing enzymes. Indeed, when bound to aliskiren the half-life of intracellular renin increased two- to threefold. ${ }^{20}$ The same applied to prorenin. This effect occurred in a concentration-dependent manner, starting at aliskiren concentrations in the low $\mu$ molar range. Such concentrations do occur in blood during aliskiren treatment, ${ }^{21}$ and, thus, assuming that this aliskiren-induced stabilization of renin and prorenin affects all clearance pathways of renin and prorenin in vivo, it is likely that this phenomenon contributes to the increase in renin after renin inhibition. The effect might be particularly apparent when combining renin inhibitors with other drugs that also stimulate renin, such as diuretics, $\mathrm{ACE}$ inhibitors and $\mathrm{AT}_{1}$ receptor antagonists. ${ }^{1}$ It is important to note that aliskiren binding did not affect the binding and internalization of renin/prorenin by mannose 6-phosphate receptors. ${ }^{20}$

Third, the renin increase may be an assay artifact, because renin inhibitors 'activate' renin's precursor, prorenin (Figure 1). ${ }^{22}$ This 'activation' is due to the fact that the prorenin prosegment is capable of unfolding from the enzymatic cleft, in a $\mathrm{pH}$ - and temperaturedependent manner, thereby resulting in two prorenin conformations: a 'closed', inactive form, and an 'open' form that displays full enzymatic activity. ${ }^{23}$ Under physiological conditions, $<2 \%$ of prorenin is in the open conformation. ${ }^{24}$ Renin inhibitors will bind to prorenin in the open conformation. Consequently, due to the presence of the renin inhibitor, the inactivation step (that is, the return to the closed conformation) is now no longer possible, and thus, the equilibrium between the closed and open conformation will shift into the direction of the open conformation. Eventually, depending on the concentration of the inhibitor, a significant proportion of prorenin may be open ('non-proteolytic activation'), allowing its recognition by the active site-directed antibodies used in the above-mentioned direct renin assays, despite the fact that the prosegment is still present (Figure 1). 20,22,25,26 This is quantitatively of major importance, as prorenin levels are normally $\approx 10$-fold higher than those of renin, ${ }^{27}$ and thus even if only a small percentage (for example, 10\%) of prorenin is recognized as renin, this will already double the immunoreactive 'renin' levels.

To determine to what degree the renin increase in humans postaliskiren actually represents prorenin, one needs a specific prorenin immunoreactive assay, based on the recognition of the prosegment. ${ }^{16,20}$ Such an assay allows the direct detection of prorenin, without requiring its conversion into renin (Figure 1). Indeed, a comparison of renin and prorenin measurements in blood samples obtained from human volunteers treated with aliskiren, both before and after prorenin activation, revealed that up to $30 \%$ of prorenin was detected in renin-specific assays (Figure 2). ${ }^{21}$ This was not an ex vivo phenomenon as a consequence of aliskiren binding to prorenin during storage and handling of the samples, because the aliskiren effect was most apparent at 24 and $48 \mathrm{~h}$ after drug intake, and not at $5 \mathrm{~h}$ after intake, when the plasma aliskiren levels were highest (and when the largest consequences of this phenomenon, if solely occurring during storage, should have occurred). Thus, aliskiren binding to prorenin in vivo may falsely lead to the detection of high 'renin' levels.

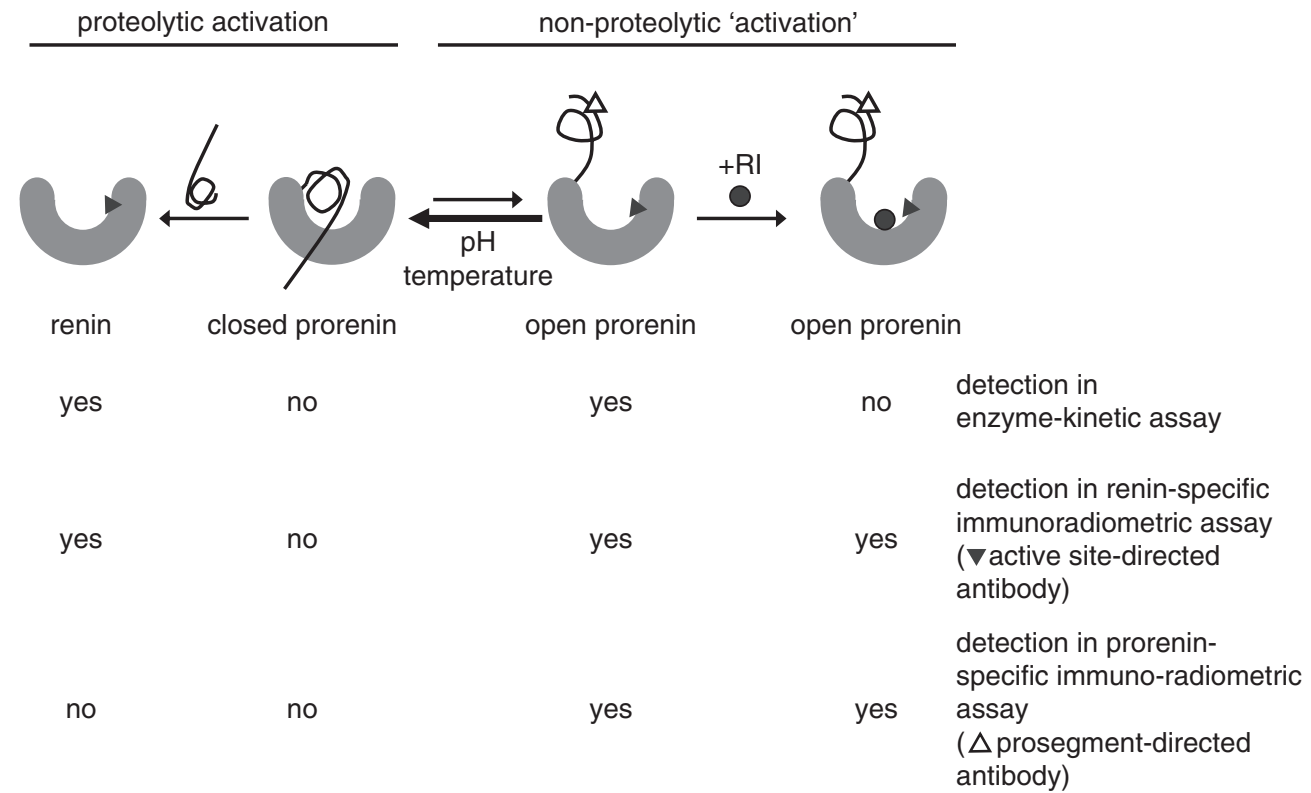

Figure 1 Scheme depicting proteolytic and non-proteolytic prorenin activation, the various prorenin configurations and the three types of assays that currently exist. Classically, prorenin is determined by subtracting the renin measurement before prorenin activation from that after prorenin activation. A prosegment assay allows the direct detection of prorenin, on the basis of its prosegment. The prosegment can only be recognized when prorenin is in the 'open' conformation. Low temperatures and low $\mathrm{pH}$ shift the equilibrium between closed and open prorenin into the direction of the latter. A renin inhibitor (RI) is capable of binding to open prorenin, thereby preventing its return to the closed conformation. See text for further explanation. Adopted from Krop et al. ${ }^{21}$ 

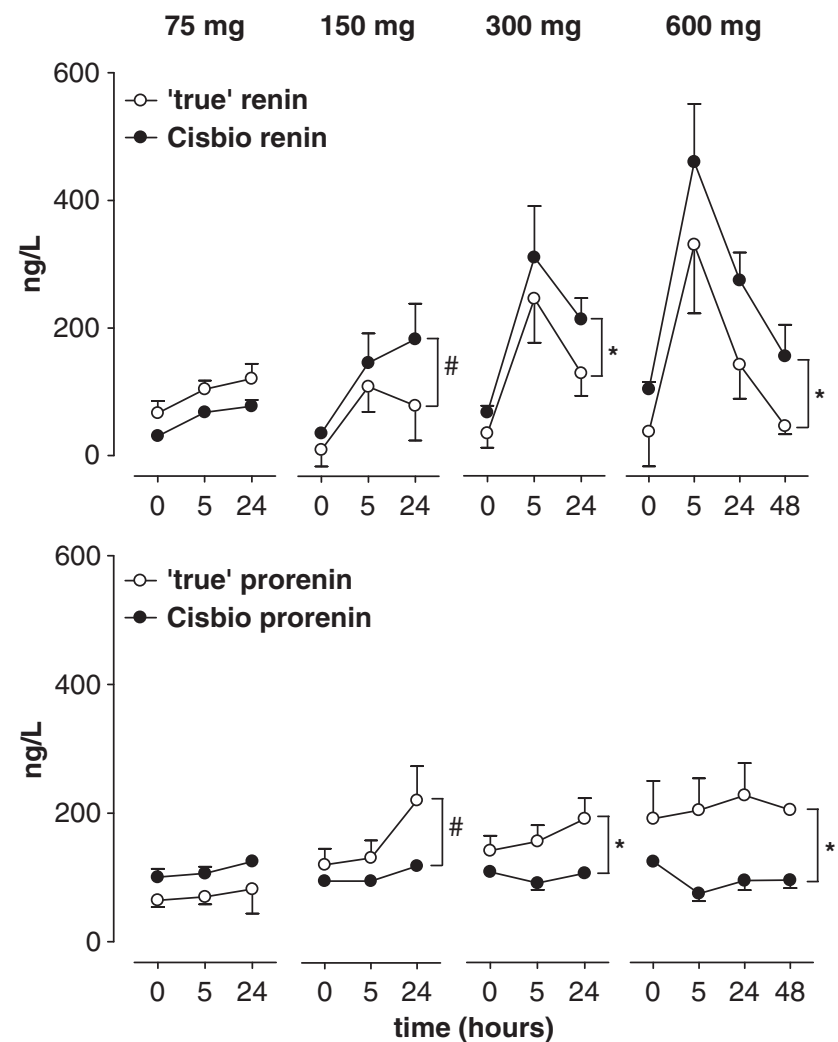

Figure 2 Renin (top) and prorenin (bottom) levels in plasma in 20 subjects on a low sodium diet after aliskiren exposure $(75-600 \mathrm{mg}$ ), measured with the active site-directed Cisbio renin immunoradiometric assay ('Cisbio' (pro)renin)) and/or a prosegment-directed assay ('true' (pro)renin)). See Figure 1 for assay characteristics. 'True' renin levels were determined by subtracting the prorenin levels measured with the prosegment assay from the total renin levels measured with the Cisbio assay. For doses greater than $75 \mathrm{mg}$, time 0 usually occurred $48 \mathrm{~h}$ after previous dose. Data are mean \pm s.e.m. $\# P<0.05$ vs. Cisbio (pro)renin; ${ }^{*} P<0.01$ vs. Cisbio (pro)renin. Adopted from Krop et al. ${ }^{21}$

In conclusion, the renin increase during aliskiren treatment is the consequence of a combination of factors, including an assay artifact, allowing the detection of prorenin as renin, and a change in renin halflife. When correcting for these phenomena the increase is unlikely to be as excessive as originally thought.

\section{DOES THE RENIN INCREASE DURING ALISKIREN RESULT IN AN ANG II ESCAPE?}

Irrespective of the cause of the renin increase and whether this increase is exaggerated or not, an aspect which merits consideration is the renin/aliskiren stoichiometry. Is the number of aliskiren molecules in blood after aliskiren sufficient to block all renin molecules, even when renin has increased several-fold? Unfortunately, immunoreactive renin measurements do not distinguish aliskiren-bound and 'free' renin, that is, they recognize aliskiren-bound renin and free renin equally well.

To address this question, we have therefore made use of the plasma measurements of renin (concentration and activity) and aliskiren in 20 healthy subjects on a low-sodium diet receiving three out of four escalating doses of aliskiren $(75,150,300$ or $600 \mathrm{mg}) .{ }^{13}$ Each subsequent aliskiren dose was given 2 days after the previous dose.
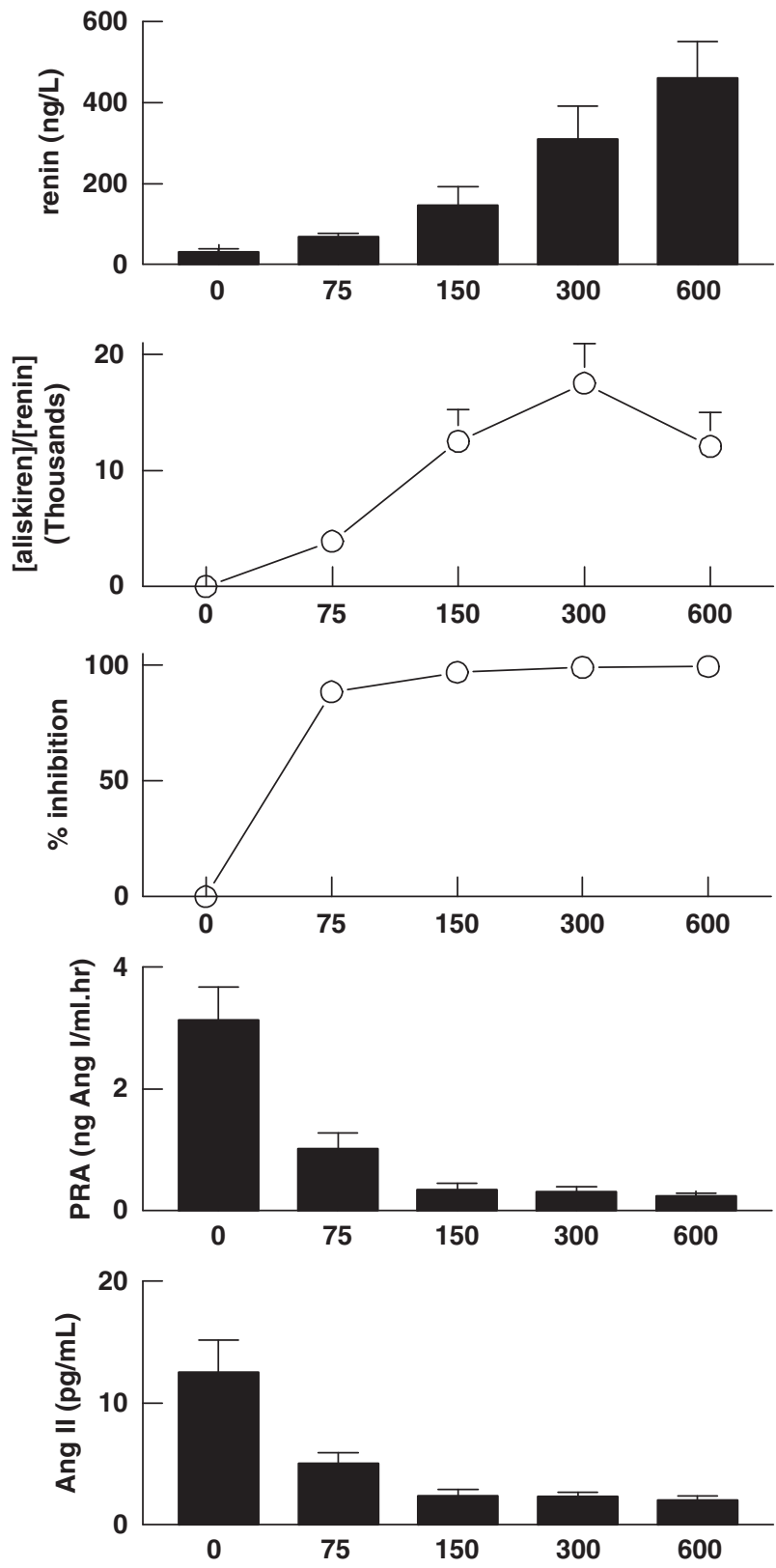

Figure 3 Plasma renin, aliskiren/renin concentration ratio, percentage renin inhibition, plasma renin activity and plasma angiotensin II at $5 \mathrm{~h}$ following during exposure of 20 healthy subjects to escalating doses of aliskiren (75, 150,300 or $600 \mathrm{mg}$ ) on separate study days. Each subsequent aliskiren dose was given 2 days after the previous dose. Data are obtained from Fisher et al. ${ }^{13}$ and Danser et al. ${ }^{28}$

Figure 3 shows the dose-dependent increases in renin and aliskiren (two top panels). It also shows that the [aliskiren]/[renin] ratio increases with each subsequent aliskiren dose up to $300 \mathrm{mg}$, reaching a ratio of almost 20.000 after $5 \mathrm{~h}$. At $600 \mathrm{mg}$, the ratio no longer increases, indicating that the increase in renin now matches the increase in aliskiren.

The percentage of renin inhibition was subsequently calculated on the basis of the aliskiren concentration, using the formula $100 \times$ [aliskiren $] /\left([\right.$ aliskiren $\left.]+\left[\mathrm{IC}_{50}\right]\right)$, where $\left[\mathrm{IC}_{50}\right]$ represents the aliskiren concentration $\left(0.6 \mathrm{nmoll}^{-1}\right)$ that is required to inhibit $50 \%$ of the renin molecules (middle panel, Figure 3 ). The data show that renin 
inhibition is $>99 \%$ at $5 \mathrm{~h}$ after the 300 and $600 \mathrm{mg}$ aliskiren doses. In fact, it was still $>95 \%$ at $24 \mathrm{~h}$ after these doses. ${ }^{28}$ The inhibition percentages reached after $150 \mathrm{mg}$ aliskiren were only marginally smaller, and correcting for the $50 \%$ of aliskiren that has been estimated to be protein-bound in plasma did not make a difference (data not shown).

Obviously, when using aliskiren in the clinically available once-daily doses of 150 and $300 \mathrm{mg}$, the steady-state aliskiren levels will be even higher than the levels reached here. Clearly, therefore, the circulating aliskiren levels during regular aliskiren treatment are more than sufficient to obtain (near-)complete renin blockade, even at trough.

The aliskiren-induced increase in renin is well below the 20-100fold increase required to overcome 95 or $99 \%$ of renin inhibition. ${ }^{13}$ In agreement with this concept, plasma renin activity decreased after aliskiren exposure (fourth panel, Figure 3), despite the increase in renin concentration. In parallel with this decrease in renin activity, aliskiren also suppressed plasma Ang II (bottom panel, Figure 3). This is in full agreement with an earlier study on the effect of aliskiren on circulating Ang I and II levels in salt-depleted volunteers. ${ }^{29}$ Therefore, an increase in Ang II during aliskiren treatment indeed does not occur: it is the stoichiometry that counts, and not the increase in renin!

Without a increase in Ang II, it is also unlikely that (some) patients might display a increase in blood pressure during aliskiren treatment, as suggested by Sealey and Laragh. ${ }^{1,30}$ In fact, both Stanton et al. ${ }^{31}$ and Nussberger et al. ${ }^{32}$ have demonstrated that the greatest blood pressurelowering effect of aliskiren occurred in patients with high baseline plasma renin activity, and the least effect in patients with low baseline plasma renin activity. ${ }^{31,32}$ Therefore, at most, low-renin patients may be resistant to aliskiren, but under no circumstances is an increase in blood pressure to be expected with aliskiren. ${ }^{31,33}$

\section{ANGIOTENSIN-INDEPENDENT EFFECTS OF (PRO)RENIN: ACTIVATION OF THE (PRO)RENIN RECEPTOR?}

Angiotensin production in organs that do not synthesize renin locally (such as the heart and vessel wall) depends on circulating (that is, kidney-derived) renin. ${ }^{34-36}$ Renin sequestration may occur by simple diffusion into the interstitium and/or binding to a receptor. ${ }^{37-39}$ Alternatively, prorenin, the inactive precursor of renin, might contribute to tissue Ang production, particularly because its plasma levels are much higher than those of renin. ${ }^{27}$ If true, a local prorenin-reninconverting mechanism should exist, to allow prorenin to display activity at tissue sites.

Recently, a (pro)renin receptor was described, ${ }^{5}$ which not only bound renin and prorenin, but which was also capable of activating prorenin: binding induced a conformational change in the prorenin molecule, allowing it to display full enzymatic activity without undergoing proteolytic cleavage to renin. ${ }^{5,20,24,40}$ Surprisingly, renin and prorenin also acted as agonists for this receptor, inducing effects in an Ang-independent manner. $5,6,8,41$

The (pro)renin receptor is a 350 -amino acid protein with a single transmembrane domain. Although it was first described on cultured human mesangial cells, ${ }^{5}$ the C-terminal part of the receptor had been described earlier as an $8.9 \mathrm{kDa}$ fragment being associated with a vacuolar $\mathrm{H}^{+}$-ATPase. ${ }^{42}$ Interestingly, (pro)renin receptor expression appeared to be upregulated under pathological conditions, for example, at cardiac tissue sites of stroke-prone spontaneously hypertensive rats on a high salt diet, ${ }^{43}$ and in the clipped kidneys of Goldblatt rats. ${ }^{44}$

The human (pro)renin receptor, when expressed in rat vascular smooth muscle cells, bound prorenin with a $K_{\mathrm{d}}$ of $6 \mathrm{nmoll}^{-1}$. Renin binding occurred with much lower affinity $\left(K_{\mathrm{d}} \geqslant 20 \mathrm{nmoll}^{-1}\right) .^{20,24,40}$ Binding was not apparent at $4{ }^{\circ} \mathrm{C}$, most likely because the majority
( $>90 \%$ ) of the (pro)renin receptors is located intracellularly, ${ }^{7}$ whereas cycling between the intracellular compartment and the cell surface occurs at $37^{\circ} \mathrm{C}$ only. The binding affinities of prorenin and renin for their receptor are 3-4 orders of magnitude above the normal levels of prorenin and renin in blood plasma $\left(\approx 5\right.$ and $\left.0.5 \mathrm{pmoll}^{-1}\right){ }^{27}$ Thus, significant prorenin binding to the (pro)renin receptor in vivo will most likely only occur at tissue sites where (pro)renin is produced locally, that is, in the kidney, ovaries, testis, adrenal and eye. ${ }^{45}$

Given the higher affinity of prorenin ( $v s$. renin) for the human (pro)renin receptor, it seems reasonable to assume that the prosegment facilitates binding, although this is clearly not the only binding determinant. Peptidic antagonists have been designed based on the idea that the prosegment of prorenin contains a 'handle region' which binds to the receptor, allowing prorenin to become catalytically active. ${ }^{46}$ These 'handle region peptides' (HRPs), mimic the handle region and thus will bind competitively to the receptor, thereby preventing receptor-mediated prorenin activation and reducing tissue RAS activity. In support of this, HRP infusion normalized the elevated renal Ang II content in diabetic rats, ${ }^{46}$ as well as the cardiac Ang II content in stroke-prone spontaneously hypertensive rats, without affecting blood pressure. ${ }^{43}$ However, HRP did not affect prorenin binding in vascular smooth muscle cells overexpressing the human (pro)renin receptor, nor the prorenin-induced Ang I generation in these cells, ${ }^{24}$ even when used at a concentrations of $1 \mu \mathrm{moll}{ }^{-1}$. Apparently, HRP is either a relatively weak antagonist, requiring concentrations $>1 \mu \mathrm{moll}^{-1}$ to exert blocking effects in vascular smooth muscle cells, or the in vivo Ang-reducing effects with this drug are exerted in an alternative, as yet unknown manner, not (only) involving the (pro)renin receptor.

(Pro)renin binding triggers activation of the mitogen-activated protein kinase (MAPK)-extracellular signal-regulated kinase (ERK)$1 / 2$ signaling pathway. ${ }^{5}$ Subsequent studies after this initial discovery confirmed ERK1/2 phosphorylation and showed that it was due to ERK kinase and provoked Ets-like (Elk) gene phosphorylation. ${ }^{6,8,41,47}$ Moreover, ERK1/2 activation resulted in the upregulation of transforming growth factor- $\beta_{1}$ gene expression, the subsequent upregulation of genes coding for profibrotic molecules such as plasminogenactivator inhibitor-1, fibronectin and collagens, and the induction of mesangial cell proliferation. ${ }^{6,41}$ The ERK1/2 pathway is not the only signaling pathway linked to the (pro)renin receptor, as the receptor also appears to activate the MAP kinase p38-heat-shock protein 27 cascade ${ }^{7,48}$ and the PI3K-p85 pathway. ${ }^{49}$ Importantly, the latter results in the nuclear translocation of the promyelocytic zinc-finger transcription factor, which downregulates the expression of the (pro)renin receptor itself. ${ }^{49,50}$ In other words, high (pro)renin levels will suppress (pro)renin receptor expression, thereby preventing excessive receptor activation.

Interestingly, the vacuolar $\mathrm{H}^{+}$-ATPase inhibitor, bafilomycin, prevented the renin- and prorenin-induced ERK1/2 phosphorylation in cultured collecting duct/distal tubule lineage Madin-Darby canine kidney cells. ${ }^{51}$ This suggests that ERK1/2 phosphorylation depends on vacuolar $\mathrm{H}^{+}$-ATPase activity. Ang II also increases the activity of vacuolar $\mathrm{H}^{+}$-ATPase in renal proximal tubule cells, mainly by increasing the apical plasma membrane expression of vacuolar $\mathrm{H}^{+}$-ATPase. ${ }^{52}$ This most likely relates to the observation that the vacuolar $\mathrm{H}^{+}$ATPase-B subunit contains binding sites to F-actin, so that an interaction between vacuolar $\mathrm{H}^{+}$-ATPase and actin filaments allows trafficking between the cytosol and the cell surface. As the p38 MAP kinase inhibitor, SB203580, inhibited such trafficking, ${ }^{52}$ it appears that p38 MAPK, following its activation by Ang II, has a role in the control of cytoskeleton proteins. The prorenin-induced stimulation of the 


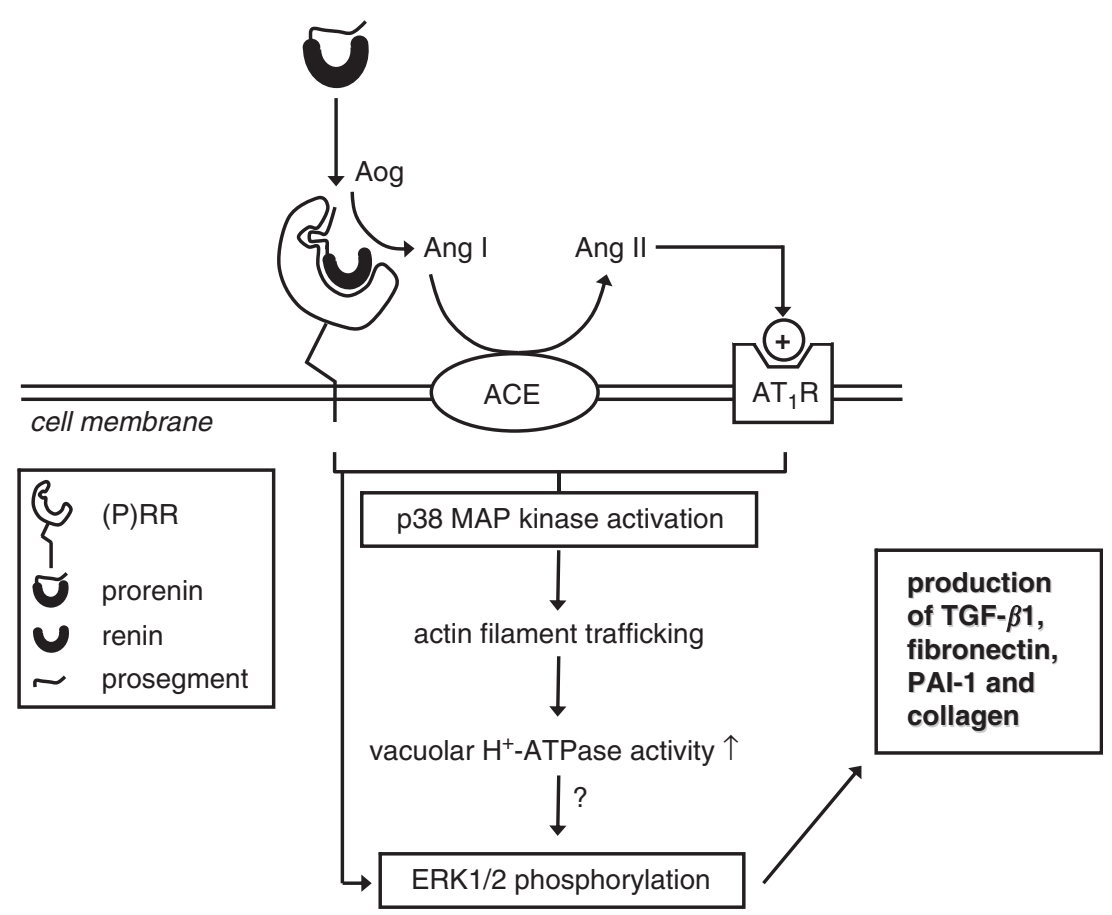

Figure 4 Schematic overview of the prorenin-(pro)renin receptor ((P)RR)-vacuolar $\mathrm{H}^{+}$-ATPase-transforming growth factor- $\beta_{1}$ (TGF- $\left.\beta_{1}\right)$ axis. (Pro)renin receptor-binding induces a conformational change in the prorenin molecule, allowing prorenin, like renin, to generate angiotensin (Ang) I from angiotensinogen (Aog), despite the fact that the prosegment is still present. In addition, renin/prorenin binding per se (that is, independently of angiotensin generation) activates intracellular signal-transduction pathways. The latter will not be blocked by a renin inhibitor. Ang II, among others, activates the same pathway. See text for further explanation. ACE, angiotensin-converting enzyme; AT ${ }_{1} R$, Ang II type 1 receptor; PAI-1, plasminogen-activator inhibitor- 1 . Adopted from Danser. ${ }^{53}$

p38-MAPK pathway also resulted in alterations in actin filament dynamics. ${ }^{7}$ Therefore, a unifying concept might be that the ERK1/2 activation by renin/prorenin is the consequence of the following order of affairs (Figure 4): renin/prorenin binding to (pro)renin receptor $\rightarrow$ p38 MAPK activation $\rightarrow$ actin filament trafficking $\rightarrow$ vacuolar $\mathrm{H}^{+}$-ATPase activity $\uparrow \rightarrow$ ERK $1 / 2$ phosphorylation. ${ }^{53}$

Results from in vivo studies in transgenic rats overexpressing the human (pro)renin receptor are in agreement with the concept of (pro)renin-induced, Ang-independent effects. ${ }^{54,55}$ The human (pro)renin receptor binds, but does not activate rat prorenin, ${ }^{54}$ and thus rat prorenin will only induce signaling by the human (pro)renin receptor. Indeed, the plasma and tissue Ang levels of transgenic rats overexpressing the human (pro)renin receptor were unaltered. Yet, these animals displayed increased levels of aldosterone in blood plasma ${ }^{54,55}$ and of cyclooxygenase- 2 in the renal cortex. ${ }^{54}$ Moreover, from the age of 7 months, they developed hypertension, ${ }^{55}$ proteinuria $^{54}$ and/or glomerulosclerosis. ${ }^{54}$ The latter was accompanied by increased MAPK p42/p44 phosphorylation and transforming growth factor- $\beta_{1}$ expression. HRP prevented the development of glomerulosclerosis. ${ }^{54}$

In contrast with these observations, glomerulosclerosis did not occur in transgenic rats with inducible prorenin expression, despite the fact that such rats, after induction, displayed a 200 -fold increase in plasma prorenin and were hypertensive. ${ }^{56}$ Moreover, HRP did not block (pro)renin-induced signaling in U937 monocytes. ${ }^{8}$ It was also ineffective in transgenic mice with 13- to 66-fold increases in circulating prorenin, although captopril rapidly normalized the hypertension in these animals. Of note, active site-mutated prorenin did not raise blood pressure in this mouse model. These data suggest that the primary consequence of chronic elevations in circulating prorenin is an Ang II-dependent increase in blood pressure. They do not support a role for prorenin as the primary causative agent in renal glomerular injury. Therefore, at present it is uncertain to what degree (pro)renin receptor overexpression truly results in (pro)renin-induced effects and whether the beneficial in vivo effects of HRP are solely due to prorenin blockade.

So far, in vitro studies do not reveal any blocking effects of aliskiren toward the direct effects of renin/prorenin by their receptor. Aliskiren neither affected the binding of renin/prorenin to the receptor, nor their signaling cascade after receptor activation. ${ }^{8,20,57}$ Aliskiren, however, did block Ang generation by receptor-bound prorenin. ${ }^{20}$ In addition, as discussed above, renin inhibitors cause the largest increase in renin of all RAS blockers. They also cause a modest increase in prorenin. ${ }^{26}$ One might argue that such an increase would result in increased (pro)renin receptor activation, thus potentially causing (detrimental) effects. Yet, no such detrimental effects have been observed during any of the many clinical trials with RAS blockers. This may relate to the (pro)renin receptor downregulation by high (pro)renin levels described by Schefe et al ${ }^{49,50}$ In fact, in full agreement with this feedback mechanism, diabetic rats treated with aliskiren showed a decrease in (pro)renin receptor expression. ${ }^{57}$ However, not all studies describe low (pro)renin receptor expression in the face of high (pro)renin levels, ${ }^{44,58}$ possibly because other factors (for example, Ang $\mathrm{II}^{59}$ ) affect (pro)renin receptor expression as well.

\section{CONCLUSIONS/PERSPECTIVES}

Both renin and prorenin increase during renin inhibition. The renin increase is larger than that seen during other types of RAS blockade. Although this could point to better RAS suppression during renin 
inhibition, two more likely reasons for this large increase are a methodological artifact (the recognition of aliskiren-bound prorenin as renin) and a change in renin half-life after its binding to aliskiren. Irrespective of the cause of the increase in renin, the aliskiren levels in blood are high enough to suppress the Ang I-generating capacity of renin, even when it has increased 10 - to 20 -fold, by $\geqslant 99 \%$ at $5 \mathrm{~h}$ after intake and still by $\geqslant 95 \%$ after $24 \mathrm{~h}$. Aliskiren will also block the enzymatic activity of prorenin when bound to the (pro)renin receptor. Therefore, it is highly unlikely that the increase in renin/prorenin will result in substantial Ang II generation, and as a consequence, an increase in blood pressure.

Aliskiren does not prevent the binding of renin/prorenin to their receptor, or the subsequent activation of intracellular signaling cascades. In other words, both renin and prorenin will still bind to the receptor when associated with aliskiren, although obviously their enzymatic activity is zero under those circumstances. Nevertheless, it should be realized that renin and prorenin also downregulate their receptor (similar to many agonists). One could even speculate that this will be more substantial when the renin and prorenin levels are higher. Thus, from this point of view the larger increase in renin during renin inhibition will cause a stronger reduction in (pro)renin receptor expression. If true, renin inhibitors would have an advantage over other types of RAS blockers, as they not only suppress Ang generation but also more strongly reduce effects mediated by the (pro)renin receptor. Studies investigating the consequences of the three types of RAS blockade under standardized conditions might address this issue. Alternatively, (pro)renin receptor blockers might display additional effects on top of RAS blockade.

\section{CONFLICT OF INTEREST}

I have received research grants from Novartis Pharmaceuticals, and I acted as advisor/consultant for them.

1 Sealey JE, Laragh JH. Aliskiren, the first renin inhibitor for treating hypertension: reactive renin secretion may limit its effectiveness. Am J Hypertens 2007; 20: 587-597.

2 van Kats JP, Duncker DJ, Haitsma DB, Schuijt MP, Niebuur R, Stubenitsky R, Boomsma F, Schalekamp MADH, Verdouw PD, Danser AHJ. Angiotensin-converting enzyme inhibition and angiotensin II type 1 receptor blockade prevent cardiac remodeling in pigs after myocardial infarction: role of tissue angiotensin II. Circulation 2000; 102: 1556-1563.

3 van Kats JP, Schalekamp MADH, Verdouw PD, Duncker DJ, Danser AHJ. Intrarenal angiotensin II: interstitial and cellular levels and site of production. Kidney Int 2001; 60: 2311-2317.

4 van Kats JP, Chai W, Duncker DJ, Schalekamp MADH, Danser AHJ. Adrenal angiotensin. Origin and site of generation. Am J Hypertens 2005; 18: 1045-1051.

5 Nguyen G, Delarue F, Burcklé C, Bouzhir L, Giller T, Sraer J-D. Pivotal role of the renin/ prorenin receptor in angiotensin II production and cellular responses to renin. J Clin Invest 2002; 109: 1417-1427.

6 Huang Y, Noble NA, Zhang J, Xu C, Border WA. Renin-stimulated TGF-beta1 expression is regulated by a mitogen-activated protein kinase in mesangial cells. Kidney Int 2007; 72: 45-52.

7 Saris JJ, "t Hoen PAC, Garrelds IM, Dekkers DHW, den Dunnen JT, Lamers JMJ, Danser AHJ. Prorenin induces intracellular signalling in cardiomyocytes independently of angiotensin II. Hypertension 2006; 48: 564-571.

8 Feldt S, Batenburg WW, Mazak I, Maschke U, Wellner M, Kvakan H, Dechend R, Fiebeler A, Burckle C, Contrepas A, Danser AHJ, Bader M, Nguyen G, Luft FC, Müller DN. Prorenin and renin-induced extracellular signal-regulated kinase $1 / 2$ activation in monocytes is not blocked by aliskiren or the handle-region peptide. Hypertension 2008; 51: 682-688.

9 Azizi M, Bissery A, Lamarre-Cliche M, Ménard J. Integrating drug pharmacokinetics for phenotyping individual renin response to angiotensin II blockade in humans. Hypertension 2004; 43: 785-790.

10 McMurray JJV, Pitt B, Latini R, Maggioni AP, Solomon SD, Keefe DL, Ford J, Verma A, Lewsey $\mathrm{J}$. Effects of the oral direct renin inhibitor aliskiren in patients with symptomatic heart failure. Circ Heart Fail 2008; 1: 17-24.

11 Parving $\mathrm{HH}$, Persson F, Lewis JB, Lewis EJ, Hollenberg NK. Aliskiren combined with losartan in type 2 diabetes and nephropathy. N Engl J Med 2008; 358: 2433-2446.
12 Oparil S, Yarows SA, Patel S, Fang H, Zhang J, Satlin A. Efficacy and safety of combined use of aliskiren and valsartan in patients with hypertension: a randomised, double-blind trial. Lancet 2007; 370: 221-229.

13 Fisher NDL, Danser AHJ, Nussberger J, Dole WP, Hollenberg NK. Renal and hormonal responses to direct renin inhibition with aliskiren in healthy humans. Circulation 2008; 117: 3199-3205.

14 Solomon SD, Appelbaum E, Manning WJ, Verma A, Berglund T, Lukashevich V, Cherif Papst C, Smith BA, Dahlof B. Effect of the direct renin inhibitor aliskiren, the angiotensin receptor blocker losartan, or both on left ventricular mass in patients with hypertension and left ventricular hypertrophy. Circulation 2009; 119: 530-537.

$15 \mathrm{Kim}$ S, Hiruma M, Ikemoto F, Yamamoto K. Importance of glycosylation for hepatic clearance of renal renin. Am J Physiol 1988; 255: E642-E651.

16 Saris JJ, Derkx FHM, de Bruin RJA, Dekkers DHW, Lamers JMJ, Saxena PR, Schalekamp MADH, Danser AHJ. High-affinity prorenin binding to cardiac man-6-P/ IGF-II receptors precedes proteolytic activation to renin. Am J Physiol 2001; 280: H1706-H1715.

17 van den Eijnden MMED, Saris JJ, de Bruin RJA, de Wit E, Sluiter W, Reudelhuber TL, Schalekamp MADH, Derkx FHM, Danser AHJ. Prorenin accumulation and activation in human endothelial cells. Importance of mannose 6-phosphate receptors. Arterioscler Thromb Vasc Biol 2001; 21: 911-916.

18 Saris JJ, van den Eijnden MMED, Lamers JMJ, Saxena PR, Schalekamp MADH, Danser AHJ. Prorenin-induced myocyte proliferation: no role for intracellular angiotensin II. Hypertension 2002; 39: 573-577.

19 Rahuel J, Priestle JP, Grutter MG. The crystal structures of recombinant glycosylated human renin alone and in complex with a transition state analog inhibitor. J Struct Biol 1991; 107: 227-236.

20 Batenburg WW, de Bruin RJA, van Gool JMG, Müller DN, Bader M, Nguyen G, Danser $\mathrm{AHJ}$. Aliskiren-binding increases the half life of renin and prorenin in rat aortic vascular smooth muscle cells. Arterioscler Thromb Vasc Biol 2008; 28: 1151-1157.

21 Krop M, Garrelds IM, de Bruin RJA, van Gool JMG, Fisher NDL, Hollenberg NK, Danser $\mathrm{AHJ}$. Aliskiren accumulates in renin secretory granules and binds plasma prorenin. Hypertension 2008; 52: 1076-1083.

22 Derkx FHM, Deinum J, Lipovski M, Verhaar M, Fischli W, Schalekamp MADH. Nonproteolytic 'activation' of prorenin by active site-directed renin inhibitors as demonstrated by renin-specific monoclonal antibody. J Biol Chem 1992; 267: 22837-22842.

23 Danser AHJ, Deinum J. Renin, prorenin and the putative (pro)renin receptor. Hypertension 2005; 46: 1069-1076.

24 Batenburg WW, Krop M, Garrelds IM, de Vries R, de Bruin RJA, Burcklé C, Müller DN, Bader M, Nguyen G, Danser AHJ. Prorenin is the endogenous agonist of the (pro)renin receptor. Binding kinetics of renin and prorenin in rat vascular smooth muscle cells overexpressing the human (pro)renin receptor. J Hypertens 2007; 25: 2441-2453.

25 Ménard J, Guyene TT, Peyrard S, Azizi M. Conformational changes in prorenin during renin inhibition in vitro and in vivo. J Hypertens 2006; 24: 529-534.

26 Schalekamp MADH, Derkx FHM, Deinum J, Danser AHJ. Newly developed renin and prorenin assays and the clinical evaluation of renin inhibitors. J Hypertens 2008; 26: 928-937.

27 Danser AHJ, Derkx FHM, Schalekamp MADH, Hense HW, Riegger GAJ, Schunkert H. Determinants of interindividual variation of renin and prorenin concentrations: evidence for a sexual dimorphism of (pro)renin levels in humans. J Hypertens 1998; 16: 853-862.

28 Danser AHJ, Charney A, Feldman DL, Nussberger J, Fisher N, Hollenberg N. The renin rise with aliskiren: it's simply stoichiometry. Hypertension 2008; 51: e27-e28.

29 Azizi M, Ménard J, Bissery A, Guyenne TT, Bura-Riviere A, Vaidyanathan S, Camisasca RP. Pharmacologic demonstration of the synergistic effects of a combination of the renin inhibitor aliskiren and the AT1 receptor antagonist valsartan on the angiotensin IIrenin feedback interruption. J Am Soc Nephrol 2004; 15: 3126-3133.

30 Sealey JE, Laragh JH. Aliskiren fails to lower blood pressure in patients who have either Iow PRA levels or whose PRA falls insufficiently or reactively rises. Am J Hypertens 2009; 22: 112-121.

31 Stanton AV, Dicker P, O'Brien ET. Aliskiren monotherapy results in the greatest and the least blood pressure lowering in patients with high- and low-baseline PRA levels, respectively. Am J Hypertens 2009; 22: 954-957.

32 Nussberger J, Gradman AH, Schmieder RE, Lins RL, Chiang Y, Prescott MF. Plasma renin and the antihypertensive effect of the orally active renin inhibitor aliskiren in clinical hypertension. Int J Clin Pract 2007; 61: 1461-1468.

33 Nussberger J, Stanton A, Fisher NDL, Hollenberg MK, Danser AHJ. Response to It is the plasma renin activity level that counts, not stoichiometry. Hypertension 2008; 52: e21.

34 Danser AHJ. Local renin-angiotensin systems: the unanswered questions. Int J Biochem Cell Biol 2003; 35: 759-768.

35 van Kesteren CAM, Saris JJ, Dekkers DHW, Lamers JMJ, Saxena PR, Schalekamp $\mathrm{MADH}$, Danser AHJ. Cultured neonatal rat cardiac myocytes and fibroblasts do not synthesize renin or angiotensinogen: evidence for stretch-induced cardiomyocyte hypertrophy independent of angiotensin II. Cardiovasc Res 1999; 43: 148-156.

36 Krop M, de Bruyn JHB, Derkx FHM, Danser AHJ. Renin and prorenin disappearance in humans post-nephrectomy: evidence for binding? Front Biosci 2008; 13: 3931-3939.

37 van den Eijnden MMED, de Bruin RJA, de Wit E, Sluiter W, Deinum J, Reudelhuber TL, Danser AHJ. Transendothelial transport of renin-angiotensin system components. J Hypertens 2002; 20: 2029-2037.

38 de Lannoy LM, Danser AHJ, van Kats JP, Schoemaker RG, Saxena PR, Schalekamp $\mathrm{MADH}$. Renin-angiotensin system components in the interstitial fluid of the isolated perfused rat heart. Local production of angiotensin I. Hypertension 1997; 29: $1240-1251$. 
39 Admiraal PJJ, van Kesteren CAM, Danser AHJ, Derkx FHM, Sluiter W, Schalekamp $\mathrm{MADH}$. Uptake and proteolytic activation of prorenin by cultured human endothelial cells. J Hypertens 1999; 17: 621-629.

40 Nabi AHMN, Kageshima A, Uddin MN, Nakagawa T, Park EY, Suzuki F. Binding properties of rat prorenin and renin to the recombinant rat renin/prorenin receptor prepared by a baculovirus expression system. Int J Mol Med 2006; 18: 483-488.

41 Huang Y, Wongamorntham S, Kasting J, McQuillan D, Owens RT, Yu L, Noble NA, Border W. Renin increases mesangial cell transforming growth factor-beta1 and matrix proteins through receptor-mediated, angiotensin II-independent mechanisms. Kidney Int 2006; 69: 105-113.

42 Ludwig J, Kerscher S, Brandt U, Pfeiffer K, Getlawi F, Apps DK, Schägger H. Identification and characterization of a novel 9.2-kDa membrane sector-associated protein of vacuolar proton-ATPase from chromaffin granules. J Biol Chem 1998; 273 : 10939-10947.

43 Ichihara A, Kaneshiro Y, Takemitsu T, Sakoda M, Suzuki F, Nakagawa T, Nishiyama A, Inagami T, Hayashi M. Nonproteolytic activation of prorenin contributes to development of cardiac fibrosis in genetic hypertension. Hypertension 2006; 47: 894-900.

44 Krebs C, Hamming I, Sadaghiani S, Steinmetz OM, Meyer-Schwesinger C, Fehr S, Stahl RA, Garrelds IM, Danser AHJ, van Goor H, Contrepas A, Nguyen G, Wenzel U. Antihypertensive therapy upregulates renin and (pro)renin receptor in the clipped kidney of Goldblatt hypertensive rats. Kidney Int 2007; 72: 725-730.

$45 \mathrm{Krop} \mathrm{M}$, Danser AHJ. Circulating versus tissue renin-angiotensin system: on the origin of (pro)renin. Curr Hyp Rep 2008; 10: 112-118.

46 Ichihara A, Hayashi M, Kaneshiro Y, Suzuki F, Nakagawa T, Tada Y, Koura Y, Nishiyama A, Okada H, Uddin MN, Nabi AH, Ishida Y, Inagami T, Saruta T. Inhibition of diabetic nephropathy by a decoy peptide corresponding to the 'handle' region for nonproteolytic activation of prorenin. J Clin Invest 2004; 114: 1128-1135.

47 Sakoda M, Ichihara A, Kaneshiro Y, Takemitsu T, Nakazato Y, Nabi AH, Nakagawa T, Suzuki F, Inagami T, Itoh H. (Pro)renin receptor-mediated activation of mitogenactivated protein kinases in human vascular smooth muscle cells. Hypertens Res 2007; 30: 1139-1146.

48 Ichihara A, Suzuki F, Nakagawa T, Kaneshiro Y, Takemitsu T, Sakoda M, Nabi AH, Nishiyama A, Sugaya T, Hayashi M, Inagami T. Prorenin receptor blockade inhibits development of glomerulosclerosis in diabetic angiotensin II type 1a receptor-deficient mice. J Am Soc Nephrol 2006; 17: 1950-1961.
49 Schefe JH, Menk M, Reinemund J, Effertz K, Hobbs RM, Pandolfi PP, Ruiz P, Unger T, Funke-Kaiser $\mathrm{H}$. A novel signal transduction cascade involving direct physical interaction of the renin/prorenin receptor with the transcription factor promyelocytic zinc finger protein. Circ Res 2006; 99: 1355-1366.

50 Schefe JH, Neumann C, Goebel M, Danser AHJ, Kirsch S, Gust R, Kintscher U, Unger T, Funke-Kaiser $\mathrm{H}$. Prorenin engages the (pro)renin receptor like renin and both ligand activities are unopposed by aliskiren. J Hypertens 2008; 26: 1787-1794.

51 Advani A, Kelly DJ, Cox AJ, White KE, Advani SL, Thai K, Connelli KA, Yuen D, Trogadis J, Herzenberg AM, Kuliszewski MA, Leong-Poi H, Gilbert RE. The (pro)renin receptor: site-specific and functional linkage to the vacuolar $\mathrm{H}^{+}$-ATPase in the kidney. Hypertension 2009; 54: 261-269.

52 Carraro-Lacroix LR, Girardi AC, Malnic G. Long-term regulation of vacuolar H(+)-ATPase by angiotensin II in proximal tubule cells. Pflugers Arch 2009; 458: 969-979.

53 Danser AHJ. (Pro)renin receptor and vacuolar $\mathrm{H}^{+}$-ATPase. Hypertension 2009; 54: 219-221.

54 Kaneshiro Y, Ichihara A, Sakoda M, Takemitsu T, Nabi AH, Uddin MN, Nakagawa T, Nishiyama A, Suzuki F, Inagami T, Itoh $\mathrm{H}$. Slowly progressive, angiotensin II-independent glomerulosclerosis in human (pro)renin receptor-transgenic rats. J Am Soc Nephrol 2007; 18: 1789-1795.

55 Burcklé CA, Danser AHJ, Müller DN, Garrelds IM, Gasc JM, Popova E, Plehm R, Peters J, Bader M, Nguyen G. Elevated blood pressure and heart rate in human renin receptor transgenic rats. Hypertension 2006; 47: 552-556.

56 Peters B, Grisk O, Becher B, Wanka H, Kuttler B, Ludemann J, Lorenz G, Rettig R, Mullins JJ, Peters J. Dose-dependent titration of prorenin and blood pressure in Cypla1ren-2 transgenic rats: absence of prorenin-induced glomerulosclerosis. J Hypertens 2008; 26: 102-109.

57 Feldman DL, Jin L, Xuan H, Contrepas A, Zhou Y, Webb RL, Müller DN, Feldt S, Cumin F, Maniara W, Persohn E, Schuetz H, Danser AHJ, Nguyen G. Effects of aliskiren on blood pressure, albuminuria, and (pro)renin receptor expression in diabetic TG(mREN2)-27 rats. Hypertension 2008; 52: 130-136.

58 Ichihara A, Sakoda M, Kurauchi-Mito A, Kaneshiro Y, Itoh H. Renin, prorenin and the kidney: a new chapter in an old saga. J Nephrol 2009; 22: 306-311.

59 Siragy HM, Huang J. Renal (pro)renin receptor upregulation in diabetic rats through enhanced angiotensin AT1 receptor and NADPH oxidase activity. Exp Physiol 2008; 93: 709-714. 